\title{
Resistin Levels in Hyperglycemic Patients
}

\section{Hiperglisemik Hastalarda Resistin Seviyeleri}

Yusuf Emrah EYi' ${ }^{1}$, Adem PARLAK ${ }^{2}$

${ }^{1}$ Department of Emergency Medicine, Presidential Guard Regiment, Ankara, Turkey

${ }^{2}$ Department of Family Medicine, Presidential Guard Regiment, Ankara, Turkey

Sayın Editör,

Derginizin 2014-2. sayısındaki "Resistin, A Potential Actor in Coronary Artery Disease" (1) başlıklı Sayın Kılıç ve arkadaşları tarafından yazılan makaleyi ilgi ile okuduk. Deneyimlerini bizlerle paylaştıkları için teşekkür ederiz. Yazarların çalışmanın yapıldı̆̆ örneklem grubunda diyabetik hasta tayininde anamnez dışında biyokimyasal parametreleri de kullanmaları gerektiği kanaatindeyiz ve bu noktaya temas etmek istiyoruz.

Yazarlar çalışmalarında hastaları koroner anjiografi sonuçlarına göre kontrol grubu ve hasta grubuna ayırdıklarını bildirmişler, diyabet tanısı olanlar ile olmayanların arasında istatistiksel açıdan fark olmadığını belirtmişlerdir ( $\mathrm{p}=0,587)$. Ancak hastaların açlık sonrası glukoz değerleri karşılaşıırıldığında hasta grubunun glukoz değerlerinin ortalaması diyabetik değerlerde bulunmuştur. Yani bu grupta diyabet tayini yapılmamış pek çok hastanın olabileceği, bu hastaların da koroner arter hastalığı insidansının kontrol grubuna göre yüksek çıkacağından resistin seviyelerinin etkileneceğini düşünmekteyiz. Hastaların HbA1c seviyeleri bakılarak gruplandırma yapılmasının çalışmanın istatistiki verileri açısından daha sağlıklı sonuçlar vereceği kanaatindeyiz.

Değerli sunumları için Kılıç ve arkadaşlarını kutlar, saygılarımızı sunarız.

Peer-review: Externally peer-reviewed.

Author Contributions: Concept - Y.E.E.; Design - Y.E.E.; Supervision - Y.E.E.; Funding - Y.E.E.; Materials - Y.E.E.; Data Collection and/or Processing - A.P.; Analysis and/or Interpretation - Y.E.E.; Literature Review - A.P.; Writing - A.P.; Critical Review - A.P.

Conflict of Interest: No conflict of interest was declared by the authors.

Financial Disclosure: The authors declared that this study has received no financial support.

Hakem Değerlendirmesi: Dış bağımsız.

Yazar Katkıları: Fikir - Y.E.E.; Tasarım - Y.E.E.; Denetleme - Y.E.E.; Kaynaklar - Y.E.E.; Malzemeler - Y.E.E.; Veri toplanması ve/veya işlemesi - A.P.; Analiz ve/veya yorum - Y.E.E.; Literatür taraması - A.P.; Yazıyı yazan - A.P.; Eleştirel İnceleme - A.P.

Çıkar Çatışması: Yazarlar çıkar çatışması bildirmemişlerdir.

Finansal Destek: Yazarlar bu çalışma için finansal destek almadıklarını beyan etmişlerdir.

\section{Kaynaklar}

1. Kılıc E, Eren N, Kırma C, Cigerli S, Turgay F, Yayla S, Abdurrahim Kocyiğit. Resistin, a potential actor in coronary artery disease. Bezmialem Science 2014; 1: 46-51. [CrossRef]

Address for Correspondence / Yazışma Adresi: Yusuf Emrah Eyi; Department of Emergency Medicine, Presidential Guard Regiment, Ankara, Turkey. Phone: +90 05325822802 E-mail: dremraheyi@yahoo.com 